\title{
Biological performance and gastrointestinal development of broiler chicks fed diets varying in energy : protein ratio
}

\author{
H. K. Swatson, R. M. Gous and P. A. Iji \\ School of Agricultural Sciences \& Agribusiness, University of Natal, P Bag X01, Scottsville 3209
}

\section{Introduction}

The productivity of poultry is partly regulated by the energy:protein (E:P) ratio of the diet, through changes in feed intake, absorption of key nutrients and metabolism of amino acids required for protein accretion (Yamauchi \& Isshiki, 1994; Bartov, 1995; Bartov \& Plavnik, 1998). The effects of varying E:P ratios on the intestinal function of poultry are less well understood. It is generally assumed that the changes in productivity observed are moderated by nutrient metabolism and alteration in the processing of dietary nutrients, including protein and energy. Nutrient processing by the gastrointestinal tract (GIT) determines the amount of nutrient that is available to the internal tissues for metabolism. The GIT utilizes an enormous amount of nutrients for self renewal and the efficiency of nutrient supply to internal tissues would be dependent on dietary factors, including E:P ratios. The present study was conducted to assess the response of the GIT to variation in dietary E:P ratio in relation to biological performance such as feed intake, feed utilization and body growth of broiler chickens.

\section{Materials and Methods}

One hundred and twenty male Ross broiler chicks were maintained on diets varying in E:P ratios. The diets were formulated using maize, maize gluten, soyabean meal, sunfower meal, soya protein isolate, fish meal and vegetable oil. Mineral and vitamin supplements were also included. There were four energy levels $(11,12,13$ or 14 MJ ME/ $/ \mathrm{kg}$ diet) and three protein levels $(250,400$ or $500 \mathrm{~g} / \mathrm{kg}$ diet). The experimental design was therefore a $4 \times 3$ factorial design, yielding $12 \mathrm{E}: \mathrm{P}$ ratios varying from 22.0 to $56 \mathrm{MJ} \mathrm{ME} / \mathrm{kg}$ protein. Birds (initial body weight $207.6 \pm 14.4 \mathrm{~g}$ ) were randomly allocated to multi-bird cages in groups of 10 . There were two replicates (cages) per treatment. The chicks were fed one of the 12 diets between 10 and 24 days of age. Feed consumption and weight gain were monitored on a weekly basis. At the end of the feeding period, three birds per cage were slaughtered through $\mathrm{CO}_{2}$ asphyxiation. The birds were dissected and the GIT removed. The full and empty weights of different regions of the tract were measured, to obtain both the tissue weight and digesta holding capacity (DHC). The proventriculus/gizzard, duodenum, jejunum, ileum and caeca were assessed, in addition to the pancreas and liver.

\section{Results and Discussion}

The effects of the dietary treatments on the biological performance of broiler chickens are summarized in Table 1. Feed intake, weight gain and feed conversion efficiency were significantly affected $(\mathrm{P}<0.001)$ by dietary protein level. Birds offered the highest E:P ratios within each energy level had significantly $(\mathrm{P}<0.001)$ better biological performance in comparison to those offered the lowest E:P ratios. Maximum growth $(43.8 \mathrm{~g} / \mathrm{b} / \mathrm{d})$ and FCE (670g gain $/ \mathrm{kg}$ feed consumed) were obtained on a diet with an E:P ratio of $52 \mathrm{MJ} \mathrm{ME} / \mathrm{kg}$ (13 MJ ME/kg, $250 \mathrm{~g}$ $\mathrm{CP} / \mathrm{kg}$ ). The lowest response was obtained on an E:P ratio of $44 \mathrm{MJ}$ ME/kg (11 MJ ME/kg, 250g CP/kg). Birds fed diets of a lower $\mathrm{CP}$ content within each $\mathrm{ME}$ level ate more feed but used that feed more efficiently $(\mathrm{P}<0.001)$ than did birds on diets containing $500 \mathrm{~g} \mathrm{CP} / \mathrm{kg}$. None of these variables was affected by interactions between dietary energy and protein levels. E:P ratios corresponding to the medium and low dietary protein levels significantly increased $(\mathrm{P}<0.01)$ the weight of the gizzard. At the higher energy levels (13 and $14 \mathrm{MJ} \mathrm{ME} / \mathrm{kg}$ diet), increasing the dietary protein density resulted in significant increases $(\mathrm{P}<0.001)$ in the weight of the gizzard. Duodenal weight varied significantly $(\mathrm{P}<0.01)$ with changes in dietary protein level, especially at high energy density. There were no significant effects of dietary energy on duodenal weights. The weight of the duodenum was reduced $(\mathrm{P}<0.01)$ as dietary protein content decreased, but only at the lowest dietary energy level. There were also significant effects $(\mathrm{P}<$ 0.01) of E:P ratio but this did not follow any definite trend. Jejunal weight was not affected by any of the main factors or E:P ratio. The empty weight of the ileum and caeca was increased $(\mathrm{P}<0.05)$ in line with an increase in dietary protein content, especially at the two lowest levels of dietary energy. The weight of the pancreas was reduced by increasing dietary energy level but this was significant $(\mathrm{P}<0.05)$ only at the highest protein level. There were 
Short paper and poster abstracts: $38^{\text {th }}$ Congress of the South African Society of Animal Science also significant effects $(\mathrm{P}<0.001)$ of dietary protein on weight of pancreas, especially at $12 \mathrm{MJ} \mathrm{ME} / \mathrm{kg}$ diet. Increasing the E:P ratio between 44 and $56 \mathrm{MJ} \mathrm{ME} / \mathrm{kg}$ protein resulted in a significant increase $(\mathrm{P}<0.001)$ in

the weight of the pancreas. Liver weight was responsive $(\mathrm{P}<0.05)$ to changes in dietary protein level but there was no definite trend.

Table 1 Effects of varying dietary energy:protein ratios on the biological performance of broiler chicks

\begin{tabular}{|c|c|c|c|c|c|c|c|}
\hline $\begin{array}{c}\text { Energy (MJ } \\
\mathrm{ME} / \mathrm{kg})\end{array}$ & $\begin{array}{c}\text { Protein } \\
(\mathrm{g} / \mathrm{kg})\end{array}$ & $\begin{array}{c}\mathrm{E}: \mathrm{P} \text { ratio } \\
(\mathrm{MJ} \mathrm{ME} / \mathrm{kg} \\
\text { protein) }\end{array}$ & $\begin{array}{l}\text { Initial } \\
\text { weight } \\
(\mathrm{g})\end{array}$ & $\begin{array}{c}\text { Final } \\
\text { weight } \\
(\mathrm{g})\end{array}$ & $\begin{array}{l}\text { Weight gain } \\
\text { (g/day) }\end{array}$ & $\begin{array}{l}\text { Feed intake } \\
\text { (g/day) }\end{array}$ & $\begin{array}{c}\text { FCE }(\mathrm{g} \\
\text { gain/kg feed) }\end{array}$ \\
\hline \multirow[t]{3}{*}{11} & 500 & 22.0 & 215.8 & $506.1^{\mathrm{c}}$ & $20.7^{\mathrm{d}}$ & $45.4^{c}$ & $460^{c}$ \\
\hline & 400 & 27.5 & 205.7 & $562.9^{\mathrm{bc}}$ & $26.7^{\mathrm{cd}}$ & $49.9^{\mathrm{bc}}$ & $530^{\mathrm{bc}}$ \\
\hline & 250 & 44.0 & 199.9 & $680.1^{\mathrm{abc}}$ & $36.1 \mathrm{a}^{\mathrm{bc}}$ & $61.8^{\mathrm{ab}}$ & $580^{\mathrm{ab}}$ \\
\hline \multirow[t]{3}{*}{12} & 500 & 24.0 & 213.9 & $535.3^{\mathrm{c}}$ & $23.0^{\mathrm{d}}$ & $46.2^{\mathrm{c}}$ & $500^{c}$ \\
\hline & 400 & 30.0 & 202.2 & $583.3^{\mathrm{bc}}$ & $28.6^{\mathrm{cd}}$ & $53.0^{\mathrm{bc}}$ & $540^{\mathrm{bc}}$ \\
\hline & 250 & 48.0 & 223.4 & $727.3^{\mathrm{ab}}$ & $38.0^{\mathrm{abc}}$ & $64.7^{\mathrm{ab}}$ & $590^{\mathrm{ab}}$ \\
\hline \multirow[t]{3}{*}{13} & 500 & 26.0 & 225.2 & $571.3^{\mathrm{c}}$ & $26.0^{\mathrm{d}}$ & $48.3^{\mathrm{c}}$ & $540^{\mathrm{bc}}$ \\
\hline & 400 & 32.5 & 196.7 & $619.6^{\mathrm{bc}}$ & $32.1^{\mathrm{cd}}$ & $50.0^{c}$ & $640^{\mathrm{a}}$ \\
\hline & 250 & 52.0 & 189.6 & $741.9^{\mathrm{a}}$ & $43.8^{\mathrm{a}}$ & $65.3^{\mathrm{ab}}$ & $670^{\mathrm{a}}$ \\
\hline \multirow[t]{3}{*}{14} & 500 & 28.0 & 208.1 & $555.3^{\mathrm{bc}}$ & $26.3^{\mathrm{d}}$ & $43.2^{c}$ & $610^{\mathrm{ab}}$ \\
\hline & 400 & 35.0 & 222.4 & $704.6^{\mathrm{ab}}$ & $36.3^{\mathrm{bc}}$ & $57.8^{\mathrm{bc}}$ & $630^{\mathrm{ab}}$ \\
\hline & 250 & 56.0 & 189.2 & $684.6^{\mathrm{ab}}$ & $37.3^{\mathrm{bc}}$ & $54.5^{\mathrm{bc}}$ & $680^{\mathrm{a}}$ \\
\hline SEM & & & 14.14 & $50.32 * *$ & $3.70 * * *$ & $4.44 * *$ & $34.0 * * *$ \\
\hline \multicolumn{8}{|l|}{ Significance } \\
\hline Energy level & & & NS & NS & $*$ & NS & $* * *$ \\
\hline Protein level & & & NS & $* * *$ & $* * *$ & $* * *$ & $* * *$ \\
\hline Energy x protein & & & NS & NS & NS & NS & NS \\
\hline
\end{tabular}

The DHC of the proventriculus/gizzard was influenced by dietary energy $(\mathrm{P}<0.001)$ and protein $(\mathrm{P}<0.01)$ levels. The effect of dietary energy was most pronounced at the low and intermediate protein levels while the protein effect was significant only at the highest energy level. The effect of E:P ratio on the DHC of proventriculus/gizzard was significant $(\mathrm{P}<0.001)$ only at the highest dietary energy level. In chicks reared on diets with the lowest protein level, the DHC of the small intestine increased $(\mathrm{P}<0.001)$ in response to an increase in dietary energy. Changes in dietary protein also influenced the DHC of the small intestine but this was significant only at an energy level of 12 MJ ME/kg diet. Changes in E:P ratio influenced the DHC of the small intestine, but this was significant $(\mathrm{P}<0.001)$ only at a dietary energy level of $12 \mathrm{MJ} \mathrm{ME} / \mathrm{kg}$. At the lowest dietary protein level, there was a significant effect $(\mathrm{P}<$ 0.001 ) of dietary energy level on caecal DHC, especially between the 11 and $13 \mathrm{MJ} \mathrm{ME} / \mathrm{kg}$ diets. The interactions between energy and protein were also significant $(\mathrm{P}<0.01)$.

\section{Conclusion}

The results obtained in this study have indicated clear effects of varying E:P ratio as well as those of the individual factors on the productive efficiency of broiler chickens. Some of these effects may partly be explained by changes in the pattern and rate of development of the GIT. These mechanisms will be verified by further examinations of the rate of protein retention in the body as a measure of the efficiency of protein utilization and investigations into the structural and functional development of intestinal mucosa.

\section{References}

Bartov, I., 1995. Br. Poult. Sci. 36, 631.

Bartov, I. \& Plavnik. I, 1998. Poult. Sci. 77, 1678.

Yamauchi, K. \& Isshiki, Y., 1994. Anim. Feed. Sci. Technol. 65, 313. 